\title{
Development of Educational Media For Type II Diabetes Mellitus Patients in the Work Area of Kedundung Health Center, Mojokerto City
}

\author{
Supriyadi ${ }^{1}$, Septa Katmawanti ${ }^{2}$, Yunita Arviolika ${ }^{3}$, and Dea Aflah Samah ${ }^{2}$ \\ ${ }^{1}$ Department of Sport Science, Faculty of Sport Science, Universitas Negeri Malang, Malang, \\ East Java, Indonesia \\ ${ }^{2}$ Department of Public Health, Faculty of Sport Science, Universitas Negeri Malang, Malang, East \\ Java, Indonesia \\ ${ }^{3}$ Department of Public Health, Faculty of Sport Science, Universitas Negeri Malang, Malang, East \\ Java, Indonesia
}

ORCID:

Septa Katmawanti: https://orcid.org/0000-0002-5115-0311

\section{Abstract}

Diabetes is one of the big four non-communicable diseases. According to the Mojokerto City Health Office, the incidence reached 3,365 in 2019 with the highest recorded

Corresponding Author:

Septa Katmawanti

septakatma.fik@um.ac.id

Published: 25 March 2021

Publishing services provided by Knowledge E

(c) Supriyadi et al. This article is distributed under the terms of the Creative Commons

Attribution License, which permits unrestricted use and redistribution provided that the original author and source are credited.

Selection and Peer-review under the responsibility of the ISMoPHS 2020 Conference Committee. at the Kedundung Health Center with 822 patients. Although the Ministry of Health has introduced dietary programmes for tackling the incidence of diabetes, a survey of the dietary rules of diabetes patients at the Kedundung Health Center revealed that it is only limited to consultation with nutritionists. Thus, it is necessary to develop a health-education media product in the form of a booklet explaining a more practical diet for diabetes mellitus patients. This study comprised of 10 stages adopted from the Sugiyono's development model using a qualitative and quantitative descriptive analysis. The booklet produced b this study is titled "How to Diet Diabetes?" and contains information on understanding diabetes diet, the purpose, the calories needed, eating schedule, type of food, diet composition, dietary restrictions, and various menus. An assessment of the final product showed that $91.6 \%$ of the media experts considered it "very worthy" and $75 \%$ of the members providing the material included in the booklet considered it "eligible with minor revision." Similarly, $92.7 \%$ of a small test group and $88.7 \%$ of a large test group classified it as "very worthy." However, further work is needed to evaluate the effectiveness and impact of the booklet. Expansion of the subject is expected so that the booklet could reach more targets.

Keywords: booklet, diabetes mellitus Diet, educational media

\section{Introduction}

Diabetes is an important health problem in society. The number of diabetics increased significantly worldwide between 1980 and 2014, from 108 million to 422 million or four times as much, Indonesia had 8.4 million diabetics in the year 2000 and predicted to 
reach 21.3 million sufferers in 2030 [1]. In the year 2018 Mojokerto City occupies the first position in the number of increasing prevalence of Type II Diabetes Mellitus as much 2.3\% [2]. Based on the survey, the incidence of Diabetes Mellitus reached 3365 cases in 2019. The highest level of Diabetes Mellitus in the working area of Mojokerto City is Kedundung Health Center, which is 822 patients.

One of the Ministry of Health's programs in overcoming the incidence of Diabetes Mellitus is Diet [3] where usually Diabetes Mellitus sufferers feel bored with the diet they are doing [4], The right way for Diabetes Mellitus patients to adhere to the diet is by providing information about the diet [5] because knowledge about the role of food and the use of food in healing disease for a patient is very important [6]. This information can be conveyed through educational media, namely booklets.

Booklet is an educational media in the form of printed books containing paper with several bound pages so that it resembles a book with a smaller size. Booklets were chosen because they can attract attention, also easy to spread and can be reached by all groups. Booklet is an effective media for use in increasing knowledge [6].

Researchers have asked for opinions from the Kedundung Community Health Center in the PTM sector through interviews related to the development of booklets as a medium for health education about the Diabetes Mellitus Diet. The Puskesmas supports the development of this booklet, because in regulating the diet of diabetes mellitus sufferers it is only limited to consulting with nutritionists and being given leaflets and there is no control over diet when the patient arrives home. Based on this background, the researchers decided to carry out research and development of nutrition booklets as a medium for health education on the Type II Diabetes Mellitus diet for Type II Diabetes Mellitus sufferers in the working area of the Kedundung Health Center, Mojokerto City.

\section{Material and Method}

This research is a type of research and development (R\&D). This development research method is research that produces a product and then tests the effectiveness of the product. In producing a suitable product, it is necessary to analyse the needs obtained by qualitative methods and to test whether the product can function optimally, further research is needed [7].

The first stage, the researcher analyse the implementation of the Diabetes Mellitus diet. The next stage is to collect literature sources and relevant previous research for consideration before developing a product. At this stage, need a analysis also carried out regarding the booklet specifications desired by the respondents. Based on the 
results of the respondent's needs, then the specifications will be determined to be developed and validated. Product validation needs to be done to find out the results of the value from the material validator and media validator and will be used to make improvements to the product that will be tested in the field. There are three components that need to be validated based on the modified BSNP, namely content presentation, graphics, and language.

The product trial phase was carried out to collect data that could be used to assess the feasibility of a booklet on the Type II Diabetes Mellitus diet. This research was conducted in December-March 2020 at the Kedundung Health Center, Mojokerto City in the Prolanis activity. Determination of the number of trial subjects in research and development is 6-8 in the small group and 15-30 in the large group [8]. The types of data obtained are qualitative data and quantitative data. Quantitative data were obtained from initial research in the form of a needs analysis questionnaire given to respondents and a validation questionnaire of two experts, namely from the nutrition sector and one media expert. This is to determine the percentage of respondents' needs in developing products as well as from product trial and product use test data. Qualitative data is data from several opinions of media experts, materials and respondents in the form of suggestions and input

The data collection instrument used in this development research was in the form of a questionnaire consisting of a questionnaire on the respondent's needs, an assessment questionnaire from experts and an assessment questionnaire from respondents during the product testing process and usage. Qualitative data in the form of suggestions and criticisms given by media experts, material experts and respondents were collected and conclusions were drawn then used as material for booklet improvements. Meanwhile, quantitative data from the results of product appraisals by respondents, material experts, and media experts were analysed using descriptive analysis techniques. Descriptive data analysis is used to analyse data by means of qualitative data converted into quantitative data. After the score is obtained, the next step is to assess the feasibility by calculating the percentage of eligibility using the following formula:

$$
P=f / N \times 100 \%
$$

Information:

$$
\begin{aligned}
& P=\text { Percentage figure } \\
& f=\text { The result score } \\
& N=\text { Totally score }
\end{aligned}
$$


After knowing the percentage, it can be seen that the media has feasible or not based on the following criteria:

TABLE 1: Feasibility assessment.

Percentage
$76 \%<$ score $\leq 100 \%$
$51 \%<$ score $\leq 75, \%$
$26 \%<$ score $\leq 50 \%$
$0 \%$ score $\leq 25 \%$

\section{Criteria}

Very worth using

Worth it with a minor revision

Quite Worth using with major revisions

Not worth using

\section{Results}

\subsection{Specification data of media requirements}

The specifications for the Diabetes Diet booklet media were carried out based on a needs analysis by the Prolanis Puskesmas Kedundung participants. The following is the result data from needs analysis activities:

1. Booklet have size A5;

2. Title "Bagaimana Cara Diet Diabetes?"

3. The colours used are Blue, Red, Green, Yellow, Brown, dan Gray

4. The types of images used are illustrative and real

5. There must be an image on every page

6. No need to use scientific words

7. The font used in Times New Romans with size 14pt

\subsection{Media expert validation}

The results of the validation by the media expert were in the form of data, an average percentage of $91.6 \%$ belonging to the criteria "Very Fit for Use". The improvements made to the booklet design are as follows:

1. Change the cover image to an illustration image

2. The food image on the cover is changed to a healthy food image

3. Writing (menu options, taboos, tips) on the cover is removed 
4. Adding procedures for reading books

5. Added material grouping by book border colour

6. Add about the author

7. Add a source to each material

8. The grid pattern is reduced

9. Do not use branded images

\subsection{Media expert validation}

The results of the material expert's validation are in the form of data, an average percentage of $75 \%$, which falls into the criteria of "eligible with minor revisions". The improvements made to the booklet design are as follows:

1. The material for calculating the number of calories is omitted

2. Calculations using percentages are replaced in the URT

3. Adding sample menus per day based on calorie needs

4. Added URT comparison

\subsection{Trial data small group}

Small group trials were carried out by directly visiting each respondent's house. Based on the trial activity on 6 prolanis participants obtained a small overall average result of $92.7 \%$ with the criteria "Very feasible to use. At this stage the respondents also provide suggestions to researchers. Here are some suggestions from respondents: Sampul dicetak dengan kertas yang lebih tebal

1. The cover is printed on heavier paper

2. Provide an illustrative image of the cooking method to make it more interesting

\subsection{Trial data large group}

Small group trials were carried out concurrently with pro-planning activities. Based on the trial activity of 30 prolanis participants obtained a small overall average result of 88.7\% with the criteria "Very feasible to use. At this stage some respondents experienced a little difficulty because they did not bring reading aids. 


\section{Discussion}

Product development and research in the form of booklet media "How to Diet Diabetes?" this is generated through a development procedure that begins with a needs analysis. The media that will be used in the educational process requires good planning. This is supported by research by Ahmadi dkk. (2017), which states that in terms of assisting an effective education process, the media must be in tune with and in accordance with the needs of respondents [9]. To obtain information from respondents about matters that are known by respondents by submitting several written statements through questionnaires [10]. Filling in a questionnaire can be done by the respondent directly, and if the respondent cannot fill it out by himself, the officer can fill it in by reading the question on the questionnaire [11].

Booklet has A5 Size $(14.8 \times 21 \mathrm{~cm})$ middle volume. The type of paper used is Art Paper $150 \mathrm{gsm}$ on the contents and $210 \mathrm{gsm}$ on the cover. This booklet consists of the title, author's name, author's agency, how to read the booklet, table of contents, bio, information on colour boundaries, material, and back cover. The Times New Romans $12 \mathrm{pt}$ and 14pt fonts. The material consists of the definition of the DM diet, goals, calorie needs, meal schedules, types of food, diet composition, dietary restrictions, examples of daily meals.

The results of the data analysis showed that the media product of the booklet "How to Diet Diabetes?" generally included in the feasible and valid category. The feasibility level of educational media is proven by a feasibility test through media validation, materials, and trials where a quantitative assessment in the form of a score and a qualitative assessment is obtained through the criticism of the suggestions given.

Product booklet "How to Diet Diabetes?" has been made through several revisions to improve the quality of the media so that it can be used optimally. The final results of this booklet product received a good response from the validators of media experts, materials and trial respondents, with the values obtained belonging to the criteria "Very Appropriate" in media validation, small group trials, large group tests and "Eligible" criteria in validation theory.

Based on the above statement, it can be concluded that the media developed has met the appropriate criteria and overall it is said to be good and can be used as a health promotion media in the Diabetes Mellitus Prolanis of the Kedundung Health Center, Mojokerto City. The results of this study are also in line with previous research by Ahmad et al. (2017) which states that the media produced shows excellent results 
with the "Very Appropriate" category on each of its assessment indicators and can be used as a medium in health education [12].

According to Notoatmodjo (in Jatmika, 2019), good health promotion media must meet several criteria for Technology, Access, Cost, Interactivity, Organization, and Novelty [13]. Booklet "How To Diet Diabetes?" it is very appropriate to be used as a media for health education on the target, considering that the condition of facilities and infrastructure that support the use of other media is not yet available in Prolanis Puskesmas Kedundung, Mojokerto City. Based on this, this booklet is a media that is easily * accessible to people with Diabetes Mellitus because it does not require a specific tool to use it (Access).

The next criterion that must be considered is the cost (Cost) incurred for making booklets. Booklets are presented in printed form, so it costs money to print them. The more the number of booklets that are printed.. the smaller the cost for each booklet. This is in line with Kurniawan's research (2017), if the costs are added up as a whole then the costs are divided by the number of products produced, it can be seen that the more products produced, the less per unit cost This is also felt by researchers, the costs used to print The 30 booklets in the large group trial were IDR 285,000 (unit cost, 285,000 / $30=9,500$ ), while the printing of 6 booklets during the small group trial at the same place was IDR 66,000 (unit cost, 66,000 / $11=11,000$ ). Regarding the costs required to print booklets, it should not be a problem when looking at the benefits and advantages that will be obtained, compared to other promotional media, booklets include printed media which require lower costs than audio and visual media [15].

The next consideration is the technology aspect. In terms of technology, the use of booklets is very simple, where its use is practical because it can be used anytime, anywhere and does not require electricity and other tools such as sound and monitors so that it is in accordance with the conditions of the facility, the implementation of prolanis at the Health Center [16]. Based on this, it can be concluded that in terms of technology the booklet "How to do a diabetes diet?" is fulfilled.

The next aspect that becomes the criterion is the interactive aspect (interactivity). Good media is what can lead to interactivity. In the booklet "How to do a diabetes diet?" There are several things that make the booklet more interesting when read. The author adds pictures, chooses colours and gives sentences that seem to invite the reader to talk. According to Bagaray (2016), a person will understand and be more excited when there is an image added to a reading, besides that it can also cause a sense of beauty [16]. The blue, red, green, yellow, brown and grey colours in this booklet also have their own meaning for readers. 
The Blue colour $(\square)$ has a calming meaning, it is hoped that in blue it can give a calming impression so that you can focus more on reading the booklet [17]. The Red colour ( $\square$ ) with full saturation it displays a hot and strong impression, because of this strong and aggressive nature, Red can be used to attract the attention of respondents reading booklets [17]. The Green Colour ( $\square$ ) can be combined with blue so that it becomes a colour combination that gives the respondent a calming impression [17]. The Yellow colour $\square$ Psychologically it is a colour that is very striking than other colours, so this colour is most suitable to attract the attention of respondents, it is hoped that it can bring respondents in a happy atmosphere when reading the booklet [17]. The Brown colour $(\square)$ is a neutral colour that is natural, warm and stable, it is hoped that using the Brown Colour will give the booklet a graceful and elegant impression [17]. The Grey colour $\square$ associated with neutral, the effect of the grey colour on a product is a balance between black and white and is very suitable for use as a supporting colour, It is hoped that grey will be the colour most easily seen by the eye so that when respondents read the booklet they do not get tired easily [17].

Booklet "How To Diet Diabetes?" it also qualifies for the Organization. Prolanis administrators provide support for the development of booklets on how to correct a diabetes diet at the Kedundung Health Center, Mojokerto City because there is no similar media in the Puskesmas. In utilizing the booklet, Prolanis received the booklet "How to Diet Diabetes?" Apart from being given to people with Diabetes Mellitus, this booklet can also help in implementing the Diabetes Mellitus Diet. With this booklet media, people with Diabetes Mellitus will get complete information about the implementation of the recommended patient's diet, accompanied by examples of daily menus based on calorie needs to make it easier for $1 \mathrm{DM}$ patient to apply the diet [20].

The last aspect that is considered to meet the criteria is novelty, namely renewability. This booklet is one type of educational media developed using an explanation in the form of images and the presence of attractive colours, so that respondents feel interested and happy when reading the booklet [20]. The development of other types of more modern media is not yet possible to implement, because according to the target situation, the use of booklets is considered the most feasible. As a companion medium, the information contained in the developed booklet must be clear, firm, and easy to understand and to make it more interesting, the development of the booklet can also be accompanied by pictures related to the material on applying the Diabetes Mellitus diet. Based on this, the existence of the booklet "How to Diet Diabetes" in prolanis at 
the Kedundung Health Center is very useful because there may not be similar media related to the implementation of the Diabetes Mellitus diet.

\section{Conclusion}

Based on the analysis of the discussion and also the results of validation activities by media and material experts, as well as the results of small and large group trials, it can be said that the booklet "How to Diet Diabetes?" This is very feasible and can be used as a medium in health promotion about the diabetes diet in people with diabetes mellitus in the working area of the Kedundung Health Center. With the advantages of the booklet, the title in this booklet has been made as attractive as possible according to the analysis of the needs of consumers / readers, the use of colour has been optimized, and does not exceed 30 pages. There are instructions for processing food ingredients that are in accordance with the diabetes mellitus diet for people with type 2 diabetes mellitus. The material presented in the booklet is made as concise and as compact as possible from reliable sources. Besides these advantages, this booklet has a weakness, namely the "How to Diet Diabetes?" This still does not fully meet the expected product specifications, because there are still some materials that have not been conveyed briefly and clearly.

\section{Acknowledgement}

None

\section{Conflict of Interest}

The authors declare that there is no conflict of interest.

\section{References}

[1] WHO. (2016). Global Report on Diabetes. Geneva: World Health Organization.

[2] Riskesdas. (2018). Hasil Utama Riskesdas. Jakarta: Kementerian Kesehatan Badan Penelitia dan Pengembangan Kesehatan, p. 66.

[3] Kemenkes. (2018). Infodatin: Hari Diabetes Sedunia: Cegah, Cegah. Dan Cegah! Jakarta: Pusat Data dan Informasi Kementerian Kesehatan RI. 
[4] Pratita, N. D. (2012). Hubungan Dukungan Pasangan Dan Health Locus of Control Dengan Kepatuhan Dalam Menjalani Proses Pengobatan Pada Penderita Diabetes Mellitus Tipe 2. Jurnal IImiah Mahasiswa Universitas Surabaya, vol. 1, issue 5, pp. 86-96.

[5] Ningrat, R. K., Kusnanto, E. U. (2019). Edukasi Latihan Keluarga Dengan Media Booklet Dan Manajemen Diet Pasien Diabetes Mellitus. Jurnal Kesehatan Masyarakat, vol. 3, issue 1, pp. 1-9.

[6] Puspita, K. D. and Rahayu, S. R. (2011). Faktor-Faktor Yang Berhubungan Dengan Perilaku Menyisakan Makanan Pasien Diit Diabetes Mellitus. Jurnal Kesehatan Masyarakat, vol. 6, issue 2, pp. 121-122.

[7] Sugiyono, P. (2015). Metode Penelitian Pendidikan. Bandung: Alfabeta.

[8] Setyosari, P. (2015). Metode Penelitian Pendidikan Dan Pengembangan. Jakarta: Kencana.

[9] Ahmadi, F., et al. (2017). Pengembangan Media Edukasi "Multimedia Indonesian Culture" (Mic) Sebagai Penguatan Pendidikan Karakter Siswa Sekolah Dasar. Jurnal Penelitian Pendidikan, vol. 34, issue 2, pp-127-136.

[10] Hermawan, I. (2019). Metodologi Penelitian Pendidikan Kuantitatif, Kualitatis Dan Mixed Methode. Jakarta: Hidayatul Quran Kuningan.

[11] Minto, R. (2010). Bahasa Indonesia Di Perguruan Tinggi. Jakarta: PT Gramedia Widiasrana Indonesia.

[12] Ahmad, A., Adi, S. and Gayatri, R. W. (2017). Pengembangan Buku Saku Sebagai Media Promosi Kesehatan Tentang Cacingan Yang Ditularkan Melalui Tanah Pada Siswa Kelas IV SDN 01 Kromengan Kabupaten Malang. Preventia, vol. 2, issue 1, pp. 25-36.

[13] Jatmika, S. E. D. J. (2019). Buku Ajar Pengembangan Media Promosi Kesehatan. Yogyakarta: K-Media.

[14] Kurniawan, D. (2017). Analisis Perilaku Biaya: Suatu Studi Komparasi Konsep Teoretis Dan Praktik Pada Biaya Produksi (Manufacturing Cost). Jurnal Substansi, vol. 1, issue 1, pp. 1-24.

[15] Farudin, A. (2011). Perbedaan Efek Konseling Gizi Dengan Media Leaflet Dan Booklet Terhadap Tingkat Pengetahuan, Asupan Energi Dan Kadar Gula Darah Pada Pasien Diabetes Melitus Di RSUD DR. Moewardi Surakarta. (Master Thesis, Fakultas IImu Kesehatan Universitas Muhammadiyah Surakarta, 2011).

[16] Bagaray, F. E. K. (2016). Efektivitas DHE Dengan Media Booklet Dan Media Flip Chart Terhadap Peningkatan Pengetahuan Kesehatan Gigi Dan Mulut Siswa SDN 126 Manado. Jurnal e-Gig, vol. 4, issue 2, pp. 76-82. 
[17] Dyah, R. (2017). Perencanaan Warna Dalam Ilustrasi Buku Berjudul "Ararufa" Yang Menggunakan Teknik Kinegram. Tangerang: Universitas Multimedia Nusantara.

[18] Setyohadi, B. (2010). Pengaruh Warna Terhadap Kamar Tidur Anak. Semarang: Universitas Negeri Semarang.

[19] Monica, M. and Luzar, L. C. (2011). Efek Warna Dalam Dunia Desain Dan Periklanan. Jurusan Desain Komunikasi Visual, vol. 2, issue 2, pp. 1084-96.

[20] Intika, T. (2018). Pengembangan Media Booklet Science for Kids Sebagai Sumber Belajar Di Sekolah Dasar. Jurnal Riset Pendidikan Dasar, vol. 1, issue 1, pp. 10-7. 